\title{
Perbedaan Kadar Zinc Rambut pada Anak Stunting dan Non Stunting Usia 12- 24 Bulan di Kelurahan Tambak Wedi Kenjeran, Surabaya
}

\section{The Difference of Hair Zinc Level on Stunted and Non Stunted Child Age 12-24 Months in Tambak Wedi Kenjeran, Surabaya}

\author{
Brigita Rainy Oktiva*1, Merryana Adriani ${ }^{1}$
}

\begin{abstract}
ABSTRAK
Latar Belakang: Permasalahan stunting masih menjadi permasalahan kesehatan di Indonesia. Prevalensi stunting di Surabaya terus mengalami peningkatan selama 3 tahun, sedangkan di Kelurahan Tambak Wedi Kenjeran prevalensi stunting pada tahun 2017 masih sangat tinggi (43,8\%). Kejadian stunting berkaitan dengan kadar zinc tubuh dikarenakan zinc berperan dalam sintesis hormon pertumbuhan. Pengukuran kadar zinc dapat dilakukan melalui rambut dalam menggambarkan kejadian stunting secara kronis. Pengukuran kadar zinc melalui rambut lebih mudah dilaksanakan dibandingkan pengukuran kadar zinc lainnya karena pengukuran kadar zinc rambut lebih sensitif dan stabil.

Tujuan: Mengetahui perbedaan kadar zinc rambut pada balita stunting dan non stunting usia 12-24 bulan di Kelurahan Tambak Wedi Kecamatan Kenjeran Surabaya.

Metode: Penelitian ini merupakan penelitian observasional analitik dengan desain cross sectional. Populasi penelitian ini adalah seluruh balita berusia 12-24 bulan di Kelurahan Tambak Wedi Kenjeran, Surabaya dengan jumlah 267 balita. Sampel penelitian ini sebesar 36 orang dengan 18 orang mengalami stunting dan 18 orang tidak stunting, diambil secara acak menggunakan teknik simple random sampling. Penentuan sampel menggunakan uji hipotesis dua proporsi. Pengumpulan data meliputi pengukuran tinggi badan, wawancara kuesioner, food recall $2 \times 24$ jam, dan pengambilan sampel rambut untuk pengukuran kadar zinc rambut dengan alat Spektofotometer Serapan Atom (SSA). Data dianalisis menggunakan uji Mann-Whitney untuk mengetahui perbedaan pada dua variabel dengan data tidak berdistribusi normal.

Hasil: Tidak terdapat perbedaan kadar zinc rambut pada balita stunting dan non stunting $(p=0,517)$. Kesimpulan: Kadar zinc rambut pada anak stunting dan non stunting dengan usia 12-24 bulan di Kelurahan Tambak Wedi Kenjeran, Surabaya tidak berbeda. Diperlukan penelitian lanjutan dengan mengukur kadar zinc tubuh secara bersamaan melalui serum darah dan rambut untuk mendapatkan hasil lebih akurat.
\end{abstract}

Kata Kunci: balita, stunting, kadar zinc rambut, zinc 


\begin{abstract}
Background: Stunted is still a health problem in Indonesia. The prevalence of stunted in Surabaya has continued to increase for 3 years, while the prevalence of stunted in Tambak Wedi Kenjeran in 2017 shows high percentage (43.8\%). Stunted are associated with zinc levels of the body due to zinc as a role in synthesis of growth hormone. Measurement of zinc levels can be done through the hair in describing chronic stunted incident. Measurement of zinc levels through the hair is easier to implement than other measurements of zinc levels, such as blood serum.

Objectives: The purpose of this study was to analyze the difference of hair zinc level in children of stunted and non stunted age 12-24 months in Tambak Wedi village, Kenjeran district, Surabaya.

Methods: This research was an observational analytic with cross sectional design. The population of this study were all children aged 12-24 months in Tambak Wedi Kenjeran, Surabaya in the amount of 267 children. The samples of this study were 36 children that divided into 18 children stunted and 18 children non-stunted, taken by simple random sampling. Data were collected by measuring height, questionnaire interview, food recall $2 \times 24$ hour, and hair zinc level measurement using Atomic Absorption Spectrophotometry (AAS). Data were analyzed using Mann-Whitney Test to find the difference in two variables with data not distributed normally.

Results: The results of this study showed no differences of hair zinc levels in stunted and non stunted children ( $p=0.517)$.

Conclusion: Hair zinc levels in stunted and non stunted children aged 12-24 months in Tambak Wedi Kenjeran, Surabaya showed no differences. Required continue research by measuring the body's zinc levels simultaneously through blood serum and hair to get more accurate results.
\end{abstract}

Keywords: toddler, stunted, hair zinc level, zinc

\footnotetext{
*Koresponden:

brigita.rainy-13@fkm.unair.ac.id

${ }^{1}$ Departemen Gizi Kesehatan, Fakultas

Kesehatan Masyarakat-Universitas Airlangga
} 


\section{PENDAHULUAN}

Stunting adalah keadaan pada anak yang menderita retardasi pertumbuhan diakibatkan oleh diet yang buruk dalam jangka waktu lama dan menjadi resiko besar untuk terserang penyakit infeksi ${ }^{[1]}$. Stunting merupakan daya ukur malnutrisi secara kronis $^{[2]}$. Indikator stunting adalah tinggi badan menurut umur (TB/U) dibawah $-2 \mathrm{SD}^{[1]}$.

Penyebab utama stunting adalah kemiskinan, sosial dan budaya, peningkatan paparan terhadap penyakit infeksi, kurangnya asupan makanan, dan akses masyarakat terhadap pelayanan kesehatan ${ }^{[3]}$. Faktor lainnya adalah berat badan lahir bayi yang rendah, yaitu $<2500$ gram $^{[4]}$. Stunting dapat memberikan dampak jangka pendek dan panjang. Dampak jangka pendek terdiri dari terhambatnya perkembangan kognitif, motorik, dan kemampuan berbahasa, selain itu juga berisiko kecacatan, terserang penyakit infeksi, hingga kematian, sedangkan dampak jangka panjang berupa berisiko penyakit degeneratif, seperti hipertensi, diabetes mellitus, penyakit jantung koroner, dan stroke, selain itu dapat berdampak pada masa dewasa yaitu menurunnya produktivitas kerja $^{[1]}$. Prevalensi balita pendek di Indonesia adalah 29\%, sedangkan prevalensi balita pendek menjadi sebuah masalah apabila melebihi $20 \%$ sehingga permasalahan stunting di Indonesia masih menjadi permasalahan kesehatan $^{[5]}$.

Kejadian stunting sangat berkaitan
dengan rendahnya asupan makanan,
terutama bahan makanan karbohidrat, protein, dan zinc. Karbohidrat berperan sebagai sumber energi utama sehingga berkaitan dengan status gizi balita ${ }^{[6]}$. Protein berperan dalam pembentukan matriks tulang sehingga berkaitan dengan pertumbuhan dan perkembangan tubuh $^{[7]}$. Zinc berperan pada pertumbuhan sel, pembelahan sel, metabolisme tubuh, sistem imunitas, dan perkembangan anak ${ }^{[8]}$. Dampak defisiensi zinc berupa kegagalan pertumbuhan dan berkurangnya volume jaringan ${ }^{[8]}$. Kadar zinc dalam tubuh dapat diketahui melalui serum darah, serta melalui rambut. Pengukuran kadar zinc pada rambut lebih tepat dalam menggambarkan keadaan kronis sehingga tepat untuk mengetahui kondisi stunting yang berlangsung lama ${ }^{[9]}$.

Kelurahan Tambak Wedi merupakan daerah pesisir kota Surabaya mendekati perbatasan Surabaya dengan Madura. Keterjangkauan masyarakat terhadap kebutuhan sehari-hari, seperti kebutuhan pangan dan pelayanan kesehatan masih dapat dijangkau, namun permasalahan gizi di Tambak Wedi masih sangat tinggi. Kejadian stunting berisiko pada anak usia 12-24 bulan, hal tersebut dikarenakan usia tersebut termasuk pada masa emas (golden age) yaitu masa kritis pertumbuhan balita ${ }^{[10]}$. Berdasarkan Operasi Timbang (2016) di Puskesmas Tambak Wedi, prevalensi stunting di Kelurahan Tambak Wedi pada balita usia 12-24 bulan di tahun 2017 adalah 43,8\% ${ }^{[11]}$. Kejadian stunting masih menjadi permasalahan kesehatan dikarenakan persentase yang tinggi. Defisiensi zinc merupakan salah satu faktor penyebab terjadinya kejadian kurang gizi kronis (stunting) ${ }^{[12]}$.Kadar zinc tubuh dapat dinilai melalui serum darah, urin, air liur, dan rambut ${ }^{[9]}$. Pengukuran kadar zinc melalui rambut dikarenakan pengukuran lebih mudah dilaksanakan. Oleh karena itu, peneliti ingin mengetahui perbedaan kadar zinc rambut pada balita stunting dan non stunting dengan usia 12-24 bulan di Kelurahan Tambak Wedi Kecamatan Kenjeran Surabaya.

\section{METODE}

Penelitian ini merupakan penelitian observasional analitik dengan desain cross sectional. Populasi penelitian ini adalah balita usia 12-24 bulan di Kelurahan Tambak Wedi Kenjeran Surabaya dengan jumlah 267 balita. Sampel penelitian ini sebesar 36 orang dengan 18 orang mengalami stunting dan 18 orang tidak stunting, cara pengambilan sampel menggunakan teknik simple random sampling. Penentuan sampel menggunakan uji hipotesis dua proporsi dengan rumus dari Kuntoro ${ }^{[13]}$. Pengambilan sampel secara acak dilakukan melalui sampel yang sudah dikelompokkan 
menjadi kelompok stunting dan non stunting. Pengumpulan data primer meliputi berat badan lahir, umur, serta jenis kelamin, pendidikan ibu, pendapatan keluarga, tingkat kecukupan asupan makanan, dan kadar zinc rambut. Kuesioner yang digunakan terdiri dari kuesioner karakteristik balita dan keluarga, food recall $2 \times 24$ jam, pengukuran tinggi badan dan pengambilan sampel rambut untuk pengukuran kadar zinc rambut dengan alat Spektofotometer Serapan Atom (SSA). Pengukuran kadar zinc rambut dilakukan di Laboratorium Fakultas Kesehatan Masyarakat. Pengambilan sampel rambut dilakukan pada bagian belakang kepala dengan memotong 1,5 - $3 \mathrm{~cm}$ dari akar rambut. Data dianalisis menggunakan uji Mann-Whitney untuk mengetahui perbedaan pada dua variabel dengan data tidak berdistribusi normal.

Penelitian ini telah mendapat persetujuan dari Komisi Etik Fakultas Kesehatan Masyarakat Universitas Airlangga Surabaya dengan nomor 363-KEPK.

\section{HASIL DAN PEMBAHASAN}

Distribusi karakteristik balita disajikan dalam Tabel 1. Hasil menunjukkan bahwa sebagian besar balita stunting dan non stunting lahir dengan berat badan lahir normal $(94,44 \%)$. Berat badan lahir rendah (BBLR) menjadi salah satu resiko terjadinya stunting pada usia 12 bulan $^{[14]}$. Namun, pada penelitian ini tidak ditunjukkan adanya perbedaan signifikan pada berat badan lahir dengan kejadian stunting. Berdasarkan hasil dari pengukuran kadar zinc rambut, balita stunting dan non stunting dengan berat badan normal cenderung memiliki kadar zinc kurang dari kadar normal. Hal tersebut menandakan bahwa berat badan lahir tidak tepat dalam menggambarkan kadar zinc pada balita stunting dan non stunting usia 12-24 bulan.

Pada Tabel 1 dicantumkan bahwa jumlah balita stunting dari usia 12-24 bulan masing-masing adalah sebesar 6 orang $(33,33 \%)$, sedangkan sebagian besar balita non stunting berusia 12-16 bulan dengan jumlah 9 orang (25\%). Semakin bertambahnya usia, resiko terjadinya stunting semakin besar ${ }^{[12]}$. Penelitian Taufiqurrahman, et al. menunjukkan bahwa balita pada kelompok usia $12-<18$ bulan sebagian besar memiliki status gizi normal atau tidak stunting ${ }^{[12]}$. Hasil pengukuran kadar zinc rambut menunjukkan bahwa beberapa balita dengan kadar zinc normal berada pada kelompok usia 12-16 bulan sehingga kadar zinc rambut pada kelompok usia 12-16 bulan kurang tepat dalam menggambarkan kejadian stunting.

Berdasarkan Tabel 1, balita stunting dan non stunting sebagian besar berjenis kelamin perempuan $(63,89 \%)$. Pada penelitian Taufiqurrahman, et al. sebagian besar balita stunting berjenis kelamin perempuan ${ }^{[12]}$. Hasil pengukuran kadar zinc rambut menunjukkan bahwa kadar zinc rambut normal sebagian besar pada jenis kelamin laki-laki. Hal tersebut menandakan bahwa pengukuran kadar zinc rambut berdasarkan jenis kelamin kurang tepat dalam menggambarkan kejadian stunting pada usia 12-24 bulan.

Distribusi karakteristik keluarga juga dicantumkan pada Tabel 1 menunjukkan bahwa sebagian besar balita stunting dan non stunting memiliki pendapatan keluarga rendah. Pendapatan keluarga berkaitan dengan kecukupan gizi keluarga, hal ini dikarenakan pendapatan rendah akan mempengaruhi daya beli bahan makanan dalam kualitas juga kuantitas ${ }^{[15]}$. Rendahnya pendapatan tersebut berdampak pada peningkatan daya beli bahan makanan rendah zinc sehingga kebutuhan zat zinc tidak terpenuhi ${ }^{[16]}$. Rendahnya asupan zat zinc dapat menimbulkan kadar zinc tubuh rendah dan berdampak pada kejadian stunting ${ }^{[9]}$. Hasil pengukuran kadar zinc rambut menunjukkan bahwa sebagian besar keluarga balita stunting dan non stunting dengan pendapatan rendah memiliki kadar zinc kurang dari normal, namun beberapa keluarga balita dengan pendapatan rendah juga memiliki kadar zinc normal. Hal tersebut menandakan bahwa pendapatan tidak tepat dalam menggambarkan kadar zinc pada balita stunting dan non stunting usia 12-24 bulan.

Dari Tabel 1, hasil penelitian menunjukkan bahwa tidak ada perbedaan antara kelompok stunting dan non stunting 
terkait faktor resiko pendidikan ibu pada penelitian ini. Pendidikan ibu berkaitan dengan pengetahuan gizi dan pola asuh terhadap balita. Hal tersebut dikarenakan ibu dengan pendidikan tinggi cenderung memliki pengetahuan gizi yang lebih luas dalam hal pemilihan bahan makanan, penyiapan bahan makanan, dan pola asuh yang benar dibandingkan dengan ibu

Tabel 1. Distribusi Karakteristik Balita, Karakteristik Keluarga, dan Tingkat Kecukupan Asupan Makanan pada Anak Stunting dan Non Stunting dengan Usia 12-24 Bulan di Keluarahan Tambak Wedi Kenjeran, Surabaya.

\begin{tabular}{|c|c|c|c|c|}
\hline \multirow{2}{*}{ Variabel } & \multicolumn{2}{|c|}{ Stunting } & \multicolumn{2}{|c|}{ Non Stunting } \\
\hline & $\mathbf{n}$ & $\%$ & $\mathbf{n}$ & $\%$ \\
\hline \multicolumn{5}{|l|}{ Berat Badan Lahir Balita } \\
\hline Tidak BBLR & 17 & 94,44 & 17 & 94,44 \\
\hline BBLR & 1 & 5,56 & 1 & 5,56 \\
\hline \multicolumn{5}{|l|}{ Usia Balita (bulan) } \\
\hline $12-16$ & 6 & 33,33 & 9 & 25 \\
\hline $17-20$ & 6 & 33,33 & 5 & 27,78 \\
\hline $21-24$ & 6 & 33,33 & 4 & 22,22 \\
\hline \multicolumn{5}{|l|}{ Jenis Kelamin (Balita) } \\
\hline Laki-Laki & 7 & 38,89 & 6 & 33,33 \\
\hline Perempuan & 11 & 61,11 & 12 & 66,67 \\
\hline \multicolumn{5}{|l|}{ Pendapatan Keluarga } \\
\hline Dibawah UMR & 17 & 94,44 & 14 & 77,78 \\
\hline Diatas UMR & 1 & 5,56 & 4 & 22,22 \\
\hline \multicolumn{5}{|l|}{ Pendidikan Ibu } \\
\hline Dasar & 13 & 72,22 & 12 & 66,67 \\
\hline Menengah & 5 & 27,78 & 4 & 22,22 \\
\hline Tinggi & 0 & 0,00 & 2 & 11,11 \\
\hline \multicolumn{5}{|c|}{ Tingkat Kecukupan Asupan Karbohidrat } \\
\hline Kurang & 18 & 100,00 & 8 & 44,44 \\
\hline Cukup & 0 & 0,00 & 8 & 44,44 \\
\hline Lebih & 0 & 0,00 & 2 & 11,12 \\
\hline \multicolumn{5}{|c|}{ Tingkat Kecukupan Asupan Protein } \\
\hline Kurang & 10 & 55,56 & 0 & 0,00 \\
\hline Cukup & 6 & 33,33 & 8 & 44,44 \\
\hline Lebih & 2 & 11,11 & 10 & 55,56 \\
\hline \multicolumn{5}{|c|}{ Tingkat Kecukupan Asupan Zinc } \\
\hline Kurang & 13 & 72,22 & 2 & 11,11 \\
\hline Cukup & 4 & 22,22 & 6 & 33,33 \\
\hline Lebih & 1 & 5,56 & 10 & 5,56 \\
\hline
\end{tabular}

Tabel 2. Distribusi Kadar Zinc Rambut pada Anak Stunting dan Non Stunting dengan Usia 12-24 Bulan di Keluarahan Tambak Wedi Kenjeran, Surabaya

\begin{tabular}{lcc}
\hline \multicolumn{1}{c}{ Nilai } & Stunting & Non Stunting \\
\hline Minimal (ppm) & 74,92 & 68,93 \\
Maksimum 9ppm) & 144,90 & 127,69 \\
Mean \pm SD & $91,31 \pm 15,07$ & $94,65 \pm 16,37$ \\
\hline
\end{tabular}


Tabel 3. Perbedaan Kadar Zinc Rambut pada Anak Stunting dan Non Stunting dengan Usia 12-24 Bulan di Kelurahan Tambak Wedi Kenjeran, Surabaya

\begin{tabular}{lccc}
\hline \multicolumn{1}{c}{ Nilai } & Stunting & Non Stunting & P-value \\
\hline Minimal (ppm) & 74,92 & 68,93 & \\
Maksimum 9ppm) & 144,90 & 127,69 & 0,517 \\
Mean \pm SD & $91,31 \pm 15,07$ & $94,65 \pm 16,37$ & \\
\hline
\end{tabular}

dengan pendidikan dasar ${ }^{[17]}$. Rendahnya pendidikan ibu dapat berdampak pada kemampuan pemilihan bahan makanan yang tidak sesuai atau tidak memenuhi kebutuhan zat gizi, seperti zat zinc sehingga dapat menimbulkan resiko stunting pada balita ${ }^{[18]}$. Hasil pengukuran kadar zinc rambut menunjukkan bahwa kadar zinc kurang normal pada balita stunting dan non stunting memiliki pendidikan ibu rendah, namun terdapat beberapa balita stunting dan non stunting dengan pendidikan ibu rendah memiliki kadar zinc normal. Hal tersebut menandakan bahwa pendidikan ibu tidak tepat dalam menggambarkan kadar zinc pada balita stunting dan non stunting usia 12-24 bulan.

Tingkat kecukupan asupan makanan terdiri dari tingkat kecukupan asupan karbohidrat, protein, dan zinc. Hasil menunjukkan bahwa balita stunting cenderung memiliki tingkat asupan makanan yang kurang. Pada tingkat kecukupan asupan karbohidrat, seluruh balita stunting memiliki asupan yang kurang. Asupan karbohidrat merupakan sumber energi yang berperan dalam pencegahan terjadi malnutrisi dan terserang penyakit infeksi ${ }^{[19]}$. Hasil penelitian menunjukkan bahwa tingkat kecukupan asupan protein pada sebagian besar balita stunting $(55,56 \%)$ termasuk pada kategori kurang. Asupan protein berperan penting dalam pertumbuhan tulang balita sehingga defisiensi asupan protein dapat menghambat laju pertumbuhan balita ${ }^{[7]}$. Selain itu, hasil penelitian menunjukkan bahwa tingkat kecukupan asupan zinc pada balita stunting $(72,22 \%)$ berada pada kategori kurang. Zat zinc berperan dalam pertumbuhan linier anak dan sebagai pencegah terjadinya stunting ${ }^{[7]}$. Berdasarkan hasil pengukuran kadar zinc rambut, balita dengan kadar zinc rambut normal memiliki tingkat kecukupan asupan makanan yang cukup dan lebih sehingga tingkat kecukupan asupan makanan mempengaruhi kadar zinc rambut. Hal tersebut dikarenakan asupan makanan merupakan faktor langsung dalam meningkatan kadar zinc tubuh, terutama melalui bahan makanan protein dan zinc ${ }^{[9]}$. Tingkat kecukupan asupan makanan dapat menggambarkan kadar zinc tubuh pada balita stunting dan non stunting usia 12-24 bulan.

Hasil penelitian menunjukkan bahwa rata-rata kadar zinc rambut pada balita stunting lebih rendah, namun tidak menunjukkan perbedaan yang bermakna. Hasil tersebut disajikan pada Tabel 2. Hasil pengukuran kadar zinc rambut menunjukkan bahwa kadar zinc pada balita stunting dan non stunting sebagian besar kurang dari normal. Kadar zinc rambut dapat menggambarkan status zinc dalam jangka waktu lama, namun adanya kontaminasi (debu, kotoran, keringat), warna, dan perawatan rambut dapat menghambat sensitifnya kadar zinc rambut sehingga dapat meningkatkan gambaran kadar zinc tubuh dari keadaan seharusnya ${ }^{[20]}$.

Data kadar zinc rambut balita pada anak stunting dan non stunting tidak berdistribusi normal sehingga menggunakan uji Mann Whitney. Analisis uji statistik MannWhitney menunjukkan bahwa tidak terdapat perbedaan kadar zinc rambut pada anak stunting dan non stunting di usia 12-24 bulan (Tabel 3). Hal tersebut sejalan dengan penelitian Susilo yang menyatakan tidak terdapat hubungan kadar zinc rambut dengan $z$-score $\mathrm{PB} / \mathrm{U}$ pada subjek berusia 12-24 bulan $^{[20]}$. Hasil tidak menunjukkan perbedaan dikarenakan sebagian besar balita baik stunting, maupun non stunting memiliki kadar zinc rambut yang rendah atau dibawah kadar normal. Hal tersebut dapat disebabkan oleh sampel rambut pada usia balita kurang sensitif dalam menggambarkan kadar zinc rambut sehingga usia tersebut kurang sesuai dalam 
mengetahui kadar zinc rambut pada anak stunting. Kadar zinc rambut dipengaruhi oleh asupan makanan. Pada usia tersebut, balita merupakan peralihan dari ASI ke makanan padat sehingga belum dapat menggambarkan kadar zinc rambut dengan tepat. Hal ini dikarenakan pada usia tersebut, balita sedang menyesuaikan dengan pola makan yang baru, yaitu dengan tambahan makanan padat. Selain itu, Air Susu Ibu (ASI) juga mempengaruhi kejadian stunting. Usia 12-24 bulan masih diberikan ASI, sehingga dapat mempengaruhi kadar zinc dalam tubuh. Hal tersebut dikarenakan pemberian ASI dapat meningkatkan kadar zinc pada balita sehingga dapat mempengaruhi gambaran kadar zinc rambut.

Kadar zinc tubuh dipengaruhi oleh faktor asupan makanan, seperti jumlah dan bentuk zat zinc yang dikonsumsi, diet yang meningkatkan absorpsi (ASI dan protein hewani) dan zat yang menghambat absorpsi (fitat, zat besi, dan kalsium) ${ }^{[21]}$. Zat zinc diserap oleh tubuh melalui jejunum dan ileum $^{[22]}$. Mekanisme zinc memasuki sel-sel mukosa melibatkan dua proses kinetik, yaitu komponen pembawa dan secara difusi, namun mekanisme melalui pembawa merupakan mekanisme utama menuju enterosit ${ }^{[23]}$. Dari enterosit, seng diikat oleh suatu protein intestinal yang disebut CysteinRich Intestinal Protein (CRIP) untuk dipindahkan ke metalotionin atau melintasi sisi serosa enterosit untuk berikatan dengan albumin $^{[24]}$. Zat zinc yang diatur oleh albumin ditranspor dari hati menuju jaringan ${ }^{[25]}$. Sebagian besar zinc disimpan dalam hati, pankreas, ginjal, otot, dan tulang ${ }^{[23]}$. Seng dalam tubuh dikeluarkan melalui tubuh, urin, feses, jaringan kulit, sel-sel mukosa dinding usus, cairan haid, dan mani ${ }^{[23]}$. Jaringan yang banyak mengandung zinc salah satunya adalah rambut, kadar zinc rambut lebih sensitif dan stabil dalam menggambarkan kadar zinc tubuh dibandingkan melalui darah dan urin ${ }^{[21]}$. Rendahnya zinc dalam tubuh dapat menghambat efek metabolit hormon pertumbuhan atau Growth Hormone sehingga sintesis dan sekresi IGF-1 (Insulin Like Growth Factor 1) berkurang. Rendahnya IGF-1 tersebut dapat menurunkan pertumbuhan epifisis tulang panjang sehingga mengalami stunting $^{[26]}$. Hasil penelitian menyatakan bahwa tidak terdapat perbedaan kadar zinc rambut pada anak stunting dan non stunting usia 12-24 bulan. Hal tersebut dikarenakan kadar zinc juga dipengaruhi oleh faktor lainnya seperti penyakit infeksi, pemberian ASI, dan karakteristik rambut, seperti jenis shampoo yang digunakan, konsumsi obat, dan suplemen yang dapat menggambarkan kadar zinc tubuh ${ }^{[27]}$.

Kelebihan dari penelitian ini adalah penelitian ini masih sangat jarang dilakukan dan penelitian mengenai kadar zinc rambut dengan kejadian stunting di Kelurahan Tambak Wedi merupakan penelitian pertama. Selain itu, metode pengukuran kadar zinc tubuh menggunakan pengukuran kadar zinc rambut dikarenakan lebih mudah dalam menggambarkan permasalahan gizi secara kronis, yaitu stunting. Kekurangan dari penelitian ini adalah pengukuran kadar zinc dilakukan hanya melalui rambut yang kurang sensitif dalam menggambarkan kadar zinc tubuh sehingga sebaiknya pengukuran zinc tubuh dilakukan secara bersamaan melalui serum darah dan rambut untuk mendapatkan hasil lebih akurat.

\section{KESIMPULAN}

Kesimpulan dari penelitian ini adalah kadar zinc rambut pada anak stunting dan non stunting dengan usia 12-24 bulan di Kelurahan Tambak Wedi Kenjeran, Surabaya tidak berbeda. Perlu dilakukan penelitian serupa dengan menambahkan riwayat pemberian ASI serta pengukuran kadar zinc pada tubuh dilakukan secara bersamaan pada serum darah dan rambut untuk mendapatkan hasil lebih akurat.

\section{ACKNOWLEDGEMENT}

Penulis ingin mengucapkan terima kasih kepada Puskesmas Tambak Wedi atas kesediaan menjadi lokasi penelitian, teman seperjuangan dalam membantu pada saat penelitian berlangsung, dan seluruh staf 
pengajar program studi sarjana ilmu gizi Universitas Airlangga atas bimbingan dan dukungan yang telah diberikan.

\section{REFERENSI}

1. World Health Organization (WHO). Nutrition Landscape Information System (NLIS) 2010. Available from http://apps.who.int/iris/bitstream/10665/ 44397/1/9789241599955_eng.pdf.

Diakses pada tanggal 8 April 2017.

2. Fikadu, T., Assegid, S., and Dube, L. Factors Associated with Stunting Among Children of Age 24 to 59 Months in Meskan District, Gurage Zone, South Ethiopia: A Case-Control Study. BMC Public Health 2014; Vol. 14: 800. Available from

https://bmcpublichealth.biomedcentral.c om/articles/10.1186/1471-2458-14-800. Diakses pada tanggal 24 April 2017.

3. Aridiyah, F. O., Rohmawati, N., dan Ririanty, M. Faktor-Faktor yang Mempengaruhi Kejadian Stunting pada Anak Balita di Wilayah Pedesaan dan Perkotaan. E-Jurnal Pustaka Kesehatan 2015; Vol. 3 (1): pp. 163-170. Available from

https://jurnal.unej.ac.id/index.php/JPK/ar ticle/download/2520/2029. Diakses pada tanggal 26 Agustus 2017.

4. Fikawati, S., Wahyuni D., and Syafiq, A. Status Gizi Ibu Hamil dan Berat Lahir Bayi pada Kelompok Vegetarian. Jurnal Makara Kesehatan 2012; Vol. 16 (1): p. 29-35. Available from http://journal.ui.ac.id/index.php/health/a rticle/viewFile/1299/1188. Diakses pada tanggal 3 Juni 2017.

5. Kementrian Kesehatan RI. Situasi Balita Pendek. Pusat Data dan Informasi (Pusdatin). 2016. Available from http://www.depkes.go.id/resources/down load/pusdatin/infodatin/situasi-balitapendek-2016.pdf. Diakses pada tanggal 25 April 2017.

6. Helmi, R. Faktor-Faktor yang Berhubunfan dengan Status Gizi pada Balita di Wilayah Kerja Puskesmas Margototo Kecamatan
Metro Kibang Kabupaten Lampung Timur. Jurnal Kesehatan 2013; Vol. IV (1): pp. 233-242. Available from http://ejurnal.poltekkes-

tjk.ac.id/index.php/JK/article/download/6 /5. Diakses pada tanggal 26 Agustus 2017.

7. Sari, E. M., Juffrie, M., Nurani, N., dan Sitaresmi, M. N. Asupan Protein, Kalsium, Fosfor pada Anak Stunting dan Tidak Stunting Usia 24-59 Bulan. Jurnal Gizi Klinik 2016; Vol. 12 (4): pp. 152-159. Available from https://jurnal.ugm.ac.id/jgki. Diakses pada tanggal 25 Agustus 2017.

8. Kusudaryati, D. P. D. Kekurangan Asupan Besi dan Seng sebagai Faktor Penyebab Stunting pada Anak. Jurnal PROFESI 2013; Vol. 10: pp. 57-61. Available from http://download.portalgaruda.org/article. php?article $=250117$. Diakses pada tanggal 26 Agustus 2017.

9. Herman, S. Review on The Problem of Zinc Deficiency, Program Prevention and Its Prospect. Media Penelitian dan Pengembangan Kesehatan Volume XIX tahun 2009. Available from http://ejournal.litbang.depkes.go.id/index .php/MPK/article/view/758/1692. Diakses pada tanggal 11 Maret 2017.

10. Ermawati, F., Muljati, S., Dewi, M., dan Safitri, A. Hubungan Panjang Badan Lahir terhadap Perkembangan Anak Usia 12 Bulan. Penel Gizi Makan 2014; Vol. 37 (2): pp. 109-118. Available from http://ejournal.litbang.depkes.go.id/index .php/pgm/article/download/4014/3831. Diakses pada tanggal 25 Agustus 2017.

11. Laporan Operasi Timbang Tahunan Puskesmas Tambak Wedi. Surabaya; 2016.

12. Taufiqurrahman, Hadi, H., Julia, M., dan Herman, S. Defisiensi Vitamin A dan Zinc sebagai Faktor Risiko Terjadinya Stunting pada Balita di Nusa Tenggara Barat. Media Penelitian dan Pengembangan Kesehatan 2009; Vol. XIX, Suplemen II. Available from http://ejournal.litbang.depkes.go.id/index .php/MPK/article/viewFile/759/1693. Diakses pada tanggal 25 Agustus 2017. 
13. Kuntoro. Metode Sampling dan Penentuan Besar Sampel. Surabaya: Pustaka Melati; 2008.

14. Wahdah, S., Juffrie, M., dan Huriyati, E. Faktor Risiko Kejadian Stunting pada Anak Umur 6-36 Bulan di Wilayah Pedalaman Kecamatan Silat Hulu, Kapas Hulu, Kalimantan Barat. Jurnal Gizi dan Dietetik Indonesia 2015; Vol. 3(2): pp. 119-130. Available from http://ejournal.almaata.ac.id/index.php/IJ ND/article/view/324. Diakses pada tanggal 26 April 2017.

15. Amirudin, M. M dan Nurhayati, F. Hubungan antara Pendapatan Orang Tua dengan Status Gizi pada Siswa SDN II Tenggong REjotangan Tulungagung. Jurnal Pendidikan Olahraga dan Kesehatan 2014; Vol. 2 (3): pp. 564-568. Available from jurnalmahasiswa.unesa.ac.id/article/1308 4/68/article.pdf. Diakses pada tanggal 26 Agustus 2017.

16. Anggraheni, N. Gambaran Kadar Serum Seng $(Z n)$ dan Z-score TB/U pada Anak Usia 9-12 Tahun. Artikel Penelitian. Semarang: Univeristas Diponegoro. Available from http://eprints.undip.ac.id/47106/1/772_N ENI_ANGGRAHENI.pdf. Diakses pada tanggal 28 Agustus 2017.

17. Handasari, E., Rosidi, A., Widyaningsih, J. Hubungan Pendidikan dan Pengetahuan Gizi Ibu dengan Tingkat Konsumsi Energi dan Protein Anak TK Nurul Bahri Desa Wukir Sari Kecamatan Batang Kabupaten Batang. Jurnal Kesehatan Masyarakat Indonesia 2010; Vol. 6 (2). Available from http://jurnal.unimus.ac.id. Diakses pada tanggal 26 Agustus 2017.

18. Anindita, P. Hubungan Tingkat Pendidikan Ibu, Pendapatan Keluargaa, Kecukupan Protein dan Zinc dengan Stunting (Pendek) pada Balita Usia 6-35 Bulan di Kecamatan Tembalang Kota Semarang. Jurnal Kesehatan Masyarakat 2012, Vol. 1 (2): pp. 617-626. Available from https://media.neliti.com/media/publicatio ns/18764-ID-hubungan-tingkatpendidikan-ibu-pendapatan-keluarga- kecukupan-protein-zinc-denga.pdf.

Diakses pada tanggal 28 Agustus 2017.

19. Ginting, M. H., Rosidi, A. and Noor, Y. Perbedaan Tingkat Kecukupan Karbohidrat dan Status Gizi (BB/TB) dengan Kejadian Bronkopneumonia Pada Balita Usia 1-5 Tahun di Puskesmas Purwoyoso Semarang. Jurnal Gizi Universitas Muhammadiyah Semarang, 2015. Vol. 4 (2). Available from http://jurnal.unimus.ac.id/index.php/jgizi/ article/view/1759/1801. Diakses pada tanggal 2 Mei 2017.

20. Susilo, M. T. Hubungan Kadar Seng (Zn) Rambut dengan Z-score Panjang Badan Menurut Umur (PB/U) Balita Usia 12-24 Bulan. Artikel Penelitian. Semarang: Universitas Diponegoro, 2013. p. 5. Available from http://eprints.undip.ac.id/41845/1/564_ MURSID_TRI_SUSILO_G2C009013.pdf. Diakses pada tanggal 11 Maret 2017.

21. Mardewi, K. W. Kadar Seng Serum Rendah sebagai Faktor Risiko Perawakan Pendek pada Anak. Tesis. Denpasar: Universitas Udayana, 2014. Available from http://www.pps.unud.ac.id/thesis/pdf_th esis/unud-978-1697957375-

tesis\%20\%20wini\%20pdf.pdf. Diakses pada tanggal 30 Agustus 2017.

22. Devi, Ch. B., Nandakishore, Th., Sangeeta, N., Basar, G., Devi, N. O., Jamir, S., Singh, M. A. Zinc in Human Health. Journal of Dental and Medical Sciences 2014, Vol. 13 (7): pp. 18-23. Available from www.iosrjournals.org. Diakses pada tanggal 30 Agustus 2017.

23. Hapsari, A. T. Kadar Seng Serum sebagai Indikator Prognosis pada Keluaran Sepsi Neonatorium. Tesis. Semarang: Univeristas Diponegoro, 2009. Available from

http://eprints.undip.ac.id/24699/1/Ariadn e_Tiara_Hapsari.pdf. Diakses pada tanggal 30 Desember 2017.

24. Hempe, JM. dan Cousins, RJ. Cysteine-rich intestinal protein and Intestinal Metallothionein: An Inverse Relationship As A Conceptual Model for Zinc Absorption in Rats. The Journal of 
Nutrition 1992; Vol. 122(1): pp. 89-95. Available from http://jn.nutrition.org/content/122/1/89.I ong. Diakses pada tanggal 30 Desember 2017.

25. Widhyari, S. D. Peran Dampak Defisiensi Zinc (Zn) Terhadap Sistem Tanggap Kebal. WARTAZOA 2012, Vol. 22 (3). Available from

http://peternakan.litbang.pertanian.go.id/ fullteks/wartazoa/wazo223-5.pdf. Diakses pada tanggal 30 Agustus 2017.

26. Damayanti, R. A., Muniroh, L., dan Farapti. Perbedaan Tingkat Kecukupan Zat Gizi dan Riwayat Pemberian ASI Eksklusif pada
Balita Stunting dan Non Stunting. Media Gizi Indonesia 2016; Vol. 11 (1), pp. 61-69. Available from http://ejournal.unair.ac.id/index.php/MGI/article/ view/4393. Diakses pada tanggal 30 Agustus 2017.

27. Rahmawati, A. Perbedaan Kadar Seng (Zn) Rambut berdasarkan Derajat Stunting pada Anak Usia 6-9 Tahun. Artikel Penelitian. Semarang: Universitas Diponegoro, 2012. Available from http://eprints.undip.ac.id/38390/1/438_A RINDHA_RAHMAWATI_G2C008007.pdf. Diakses pada tanggal 30 Juli 2017. 